\title{
The Composition of Room with Acoustical Applications in the Ensemble Room of Purwacaraka College of Music
}

\author{
Tamara Vania $^{1^{*}}$ Adi Ismanto ${ }^{1}$ Aing R. Nayadilaga ${ }^{1}$ \\ ${ }^{1}$ Interior Design Study Program, Faculty of Art and Design, Universitas Tarumanagara, Jakarta, Indonesia \\ "Corresponding author. Email: tamara.615170062@stu.untar.ac.id
}

\begin{abstract}
Music in Indonesia is increasingly developing and in demand so now many people have studied music professionally to make a living. Purwacaraka College of Music was formed with the purpose of meeting the community's need for deepening music science. As a music school, a music room is the school's main requirement, which requires acoustic treatments to produce good quality music sound. The purpose of writing this journal is to examine the application of acoustics to the spatial composition of the ensemble room of school. The research method used is descriptive analysis with a qualitative approach and data were collected through literature studies. The results of this study are room compositions with the applications of acoustics that are applied to the ensemble room of the Purwacaraka College of Music through the arrangement of the layout, determining the size of the space, as well as the application of diffusers, sound absorbing functions, etc. on floors, walls, and ceilings to support the acoustics of the ensemble space.
\end{abstract}

\section{Keywords: Acoustic, Ensemble, Room Composition, Music}

\section{INTRODUCTION}

Music is the art of composing sounds or voices that are contained in every human civilization. In addition, music in another sense is the spark of human feelings or thoughts, so as an expression of human feelings, there is not even a history of human civilization that is passed without music. (Sutanto in Alfajar, 2014) [1]

Just like in other countries, the development of music in Indonesia is also growing and in demand. The high public's interest in music makes many people want to study music professionally as a provision for the future due to the high interest in music at this time.

As a music school, the music room is the main requirement of the school and in music room, acoustics is a very important part because acoustics affects the quality of sound and music in a space.

According to $k b b i$ [4], acoustics is a branch of physics that investigates the production, control, delivery, acceptance, and influence of sound. Therefore, in designing the Purwacaraka College of Music, acoustics in the music practice room is prioritized in order to produce good sound quality so that the teaching and learning activities can be carried out optimally in order to produce high quality graduates to improve the quality of Indonesian music.

Reporting from the book Crafts and Music Arts (1996) by A. Yudana Basuki [9], ensemble music is a form of presenting music played by several people using certain musical instruments, as well as playing simple songs. The music is divided into 2 types based on the type of musical instrument used, namely similar and mixed ensembles.
1. Similar Ensembles

The definition of a similar ensemble is a song play that uses the same type of musical instrument that is played by several people simultaneously.

2. Mixed Ensembles

Mixed ensembles are song games using several different types of musical instruments played by several people. In the mixed ensemble game, cooperation between all musical instrument players is needed to create song harmonization using different musical instruments.

From this definition, it can be concluded that ensemble room is a space used for music played by several people with various kinds of musical instruments.

\subsection{Music Class Acoustics Requirements}

Noise control is the key to the success of a music studio. This control is viewed from two things, namely:

1. Withstand the entry of outside noise

2. Withstand the escape of inside noise

To reduce the entry and exit of vibrations from outside and from within the study room, the floor should be designed with a raised floor model; the ceiling frame should ideally not be attached to the roof frame, but instead installed hanging; The wall is designed as a double wall of a different material with an air-filled intermediate cavity. (Mediastika, 2005) [6]. 
In designing very acoustically sensitive spaces such as concert halls or recording studios, one should pay attention to frequencies of one octave below (63 or $64 \mathrm{~Hz}$ ) and one octave above $(8000$ or $8192 \mathrm{~Hz})$ the standard frequency range. (Doelle, 2010) [3].

According to Doelle (2010) [3], in the acoustics of an auditorium, it is necessary to pay attention to the diffusion of sound (the spread of sound) in the room, two things that must be considered in the effort to provide diffusion in irregular surface spaces (highlighted building elements, closed ceilings, jagged walls, etc.) should be widely used, and must be large enough. Processing the surface shape of space-forming elements, especially in the walls and ceilings with an irregular arrangement and in sufficient number and size, will greatly improve listening conditions, especially in spaces with long reverberation times. This can also be applied to ensemble rooms which require good acoustic requirements.

In addition, good reverberation control is also needed. The extension of the sound as a result of repeated reflection in an enclosed space after the sound source has been turned off is called buzzing. This needs to be considered so that the sound lasts well for quite sometime. In addition, the space must also be free from acoustic defects which can be overcame by using sound-absorbing materials on reflected surfaces. (Doelle, 2010) [3].

For the function of the music room, the reverberation time can increase the interesting quality of the sound so that the sound produced by a musical instrument feels alive. In addition, the greater the volume of the room, the longer the required reverberation time is.

In the journal of Designing small music practice rooms for sound quality by Osman (2010) [8], it is said that the Reverberation time (RT) is probably the most widely used parameter in room acoustics, and is usually measured using the Schroeder integrated impulse response technique [Schroeder, 1965], and linear regression between -5 and -35 $\mathrm{dB}$ (or $-25 \mathrm{~dB}$ when the dynamic range is insufficient) [Pelorson et al, 1992].

Table 1 Recommended Reverberation Times for Small Music Rooms [8]

\begin{tabular}{|c|c|c|c|c|c|}
\hline Room & Area $\left(\mathbf{m}^{\mathbf{2}}\right)$ & Volume $\left(\mathbf{m}^{\mathbf{3}}\right)$ & $\mathbf{A S 2 1 0 7 , 2 0 0 0}$ & DfES, 2002 & ANSI S12.60 \\
\hline Ensemble / Music Studio & $16-50$ & $38-150$ & $0.7-0.9$ & $0.5-1.0$ & $<0.6$ \\
\hline
\end{tabular}

Source: AS2107-2000, ANSI S12.60-2002, DfES,2002 in Designing small music practice rooms for sound quality Journal

Table 2 Recommended Maximum Background Noise Levels [8]

\begin{tabular}{|c|c|c|c|c|}
\hline Room & Cav.(1990) & AS2107,2000 & DfES,2002 & ANSI,2002 \\
\hline Rehearsal Room & $35 \mathrm{dBA}$ & $35 \mathrm{dBA}$ & $30 \mathrm{dBA}$ & $35 \mathrm{dBA}$ \\
\hline Music Classroom & $35 \mathrm{dBA}$ & $40 \mathrm{dBA}$ & $30 \mathrm{dBA}$ & $35 \mathrm{dBA}$ \\
\hline Ensemble Practice & $38 \mathrm{dBA}$ & $45 \mathrm{dBA}$ & $30 \mathrm{dBA}$ & $35 \mathrm{dBA}$ \\
\hline
\end{tabular}

Source: AS2107-2000, Cavanaugh,1990, ANSI S12.60-2002, DfES,2002 in Designing small music practice rooms for sound quality Journal

Various types of musical instruments have different requirements from a small music practice room. Issues to be taken into consideration are the potential sound power that can be generated by the instrument, the frequency range of the instrument and the type of instrument itself (wind, string, percussion etc.). This would determine the sound insulation requirements between music rooms and the type of internal acoustic treatment (Osman, 2010) [8].

Table 3 Preferred Reverberation Time by Instrument Type [8]

\begin{tabular}{|c|c|}
\hline Instrument Type & Preferred RT \\
\hline Percussion Instruments & $0.3-0.5$ secs \\
\hline Bowed String Instruments (violin, cello) & $0.6-0.9$ secs \\
\hline Wind Instruments (trumpet, flute) & $0.4-0.7$ secs \\
\hline
\end{tabular}

Table 4 Frequency Range of Vocals and Musical Instruments [2]

\begin{tabular}{|c|c|}
\hline Musical Instruments & Frequency \\
\hline Vocal & $80 \mathrm{~Hz}$ (Bass) - 1Khz (Soprano) \\
\hline Saxophone & $55 \mathrm{~Hz}$ (Bass saxophone) $-1 \mathrm{KHz}$ (Soprano saxophone) \\
\hline Violin & $200 \mathrm{~Hz}-3.5 \mathrm{KHz}$ \\
\hline Double Bass & $40 \mathrm{~Hz}-200 \mathrm{~Hz}$ \\
\hline Guitar & $80 \mathrm{~Hz}-630 \mathrm{~Hz}$ \\
\hline
\end{tabular}




\begin{tabular}{|c|c|}
\hline Piano & $28 \mathrm{~Hz}-4.1 \mathrm{KHz}$ \\
\hline Organ & $20 \mathrm{~Hz}-7 \mathrm{KHz}$ \\
\hline Percussion & $260 \mathrm{~Hz}-3.5 \mathrm{KHz}$ \\
\hline
\end{tabular}

Osman (2010) [8] in journal of Designing small music practice rooms for sound quality, provides recommendations for room dimension ratio for music room.

Table 5 Recommended Room Dimension Ratios for Small Rooms [8]

\begin{tabular}{|c|c|}
\hline Ratio Name & Room Dimension Ratio \\
\hline Harmonic & $1: 2: 3$ \\
\hline V.O.Knudsen & $1.6: 3: 4$ \\
\hline European & $3: 5: 8$ \\
\hline J.E.Volkmann & $1: 1.6: 2.5$ \\
\hline Golden Ratio & $1: 1.25: 1.6$ \\
\hline
\end{tabular}

Doelle (2010) [3] describes the sound-absorbing materials used in acoustic design that are used as sound control in noisy spaces and can be installed on the walls of the room or hung as space absorbers, namely those that are porous and absorbent panels and carpet.

1. Porous Material

Acoustic materials that fall into this category are fiber boards, soft plasters, mineral wools and insulation blankets. The basic characteristic of all such porous materials is that they convert the incoming sound energy into heat energy in the pores and are absorbed, while the rest energy that has reduced is reflected by the surface of the material. Porous acoustic materials can be divided into 2 categories, namely: ready-to-use acoustic units, and spray-on materials.

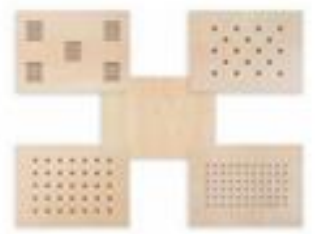

Figure 1 Perforated Acoustic Material

2. Absorbent Panel

Absorbent panel is an impermeable material that is attached to a solid support layer (solid baking) but separated by a hollow space.

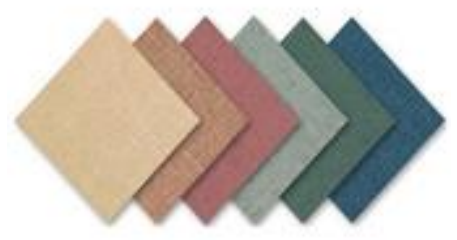

Figure 2 Absorbent Panel

Table 6 Materials Absorption Coefficients

\begin{tabular}{|c|c|c|c|c|c|c|}
\hline \multirow{2}{*}{ Material } & \multicolumn{6}{|c|}{ Absorption Coefficients in Every Frequency } \\
\hline & $125 \mathrm{~Hz}$ & $250 \mathrm{~Hz}$ & $500 \mathrm{~Hz}$ & $1000 \mathrm{~Hz}$ & $2000 \mathrm{~Hz}$ & $4000 \mathrm{~Hz}$ \\
\hline $\begin{array}{l}\text { 2x plasterboard on frame, with } \\
\text { mineral wool }\end{array}$ & 0,15 & 0,10 & 0,06 & 0,04 & 0,04 & 0,05 \\
\hline $\begin{array}{l}12 \mathrm{~mm} \text { plywood containing } \\
\text { glasswool }\end{array}$ & 0,40 & 0,20 & 0,15 & 0,10 & 0,10 & 0,05 \\
\hline Glasswool $50 \mathrm{~mm}, 33 \mathrm{~kg} / \mathrm{m} 3$ & 0,20 & 0,55 & 1,00 & 1,00 & 1,00 & 1,00 \\
\hline $\begin{array}{c}\text { Vinyl+underlay stuck to } \\
\text { cencrete }\end{array}$ & 0,02 & 0,02 & 0,04 & 0,05 & 0,05 & 0,1 \\
\hline $\begin{array}{l}\text { Cloth-upholstered seats, per } \\
\mathrm{m} 2\end{array}$ & 0,44 & 0,60 & 0,77 & 0,89 & 0,82 & 0,70 \\
\hline
\end{tabular}

\section{Source www.acoustic.ua}

The absorption coefficient of some materials such as plywood and plasterboard is higher at low frequencies, indicating that these materials are more effective at absorbing bass and other low frequency sounds, while materials such as glasswool and absorbent panels, have a higher absorption coefficient as the frequency increases, indicating that the material is more effective at absorbing high frequency sounds such as the sound of violin and soprano saxophone. 
Table 7 Absorption Coefficient and NRC value of common materials [5]

\begin{tabular}{|c|c|c|c|c|c|c|c|}
\hline Staterial & $x_{125}$ & $\alpha_{\mathrm{ng}}$ & $\alpha_{\operatorname{mon}}$ & $\alpha_{n=0}$ & $x_{i=}=$ & "xases & NkC \\
\hline 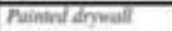 & Q. & 00 & 005 & 60 & 00 & का & ing \\
\hline Fhater & 80 & 003 & 604 & 6.05 & 604 & कबा & 605 \\
\hline Simedi indmere & बर० & 0.05 & 0.00 & 907 & 00 & am & $0 \omega$ \\
\hline Coarse cometivis & 036 & $a+4$ & 031 & 0.29 & 0.5 & 0.35 & 0.35 \\
\hline Smoothont & 003 & 001 & क्या & 805 & उल & बल & 00 \\
\hline Glats & 605 & 0.09 & 002 & 0.02 & 0.03 & $60 \mathrm{~s}$ & 005 \\
\hline Menulbling & 000 & बक्ष & कान & 0.15 & 0.13 & 0.17 & 010 \\
\hline Find & 205 & 0.4 & a.7 & 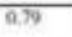 & 0.1 & 6.7x & 0.70 \\
\hline Leptrowavy & $\overline{60}$ & (1904 & बII & 0.17 & 0.24 & 0.35 & 0.15 \\
\hline Heny dingeny & at & 0.35 & 055 & a.72 & $0 \times 0$ & ans & an \\
\hline 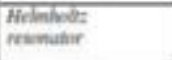 & $\alpha \div 0$ & 0.95 & 0.55 & 0,40 & 0.53 & 0.50 & $0 \times 0$ \\
\hline 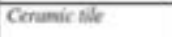 & 001 & 0.01 & 601 & 0.01 & $\sigma \omega 2$ & ans & $\omega \omega$ \\
\hline Diminum & का & 0003 & 003 & 605 & 003 & 80 & 005 \\
\hline Cappet & कos & 0.05 & 210 & 030 & 0.30 & 640 & 0.15 \\
\hline 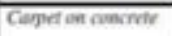 & 606 & 0.10 & 015 & 0.10 & 0,50 & 055 & 0.85 \\
\hline 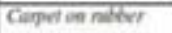 & 000 & 0.15 & 013 & $0+0$ & $\overline{0.0}$ & बखा & $\overline{0.30}$ \\
\hline
\end{tabular}

simdos.unud.ac.id

In general, materials with an NRC (Noise Reduction Coefficient) value below 0.20 are reflective, while materials with an NRC value above 0.40 are absorbent.

\section{METHODS}

This study analyzes acoustics of the ensemble room's composition in Purwacaraka College of Music based on the materials and acoustical function that are applied to the space. The method used is descriptive analysis with a qualitative approach. Moleong (2007) [7] suggests a qualitative method as a research procedure that produces descriptive data in the form of words or verbs from people and observable behavior.

The data collection method used was document study, which collecting data from book sources.

\section{FINDINGS AND DISCUSSIONS}

In designing the acoustic ensemble room of Purwacaraka College of music, it is based on the theory that has been obtained. The size of the Ensemble room is $91.7 \mathrm{~m}^{2}$. With a space length of $10 \mathrm{~m}$ and a width of $9.17 \mathrm{~m}$, and using the recommended space ratio V.O. Knudsen which is 1.6:3:4 (Table 5), so with some rounding, a ceiling height of $5 \mathrm{~m}$ is used. This is intended to achieve a propotion of space that is good acoustically.

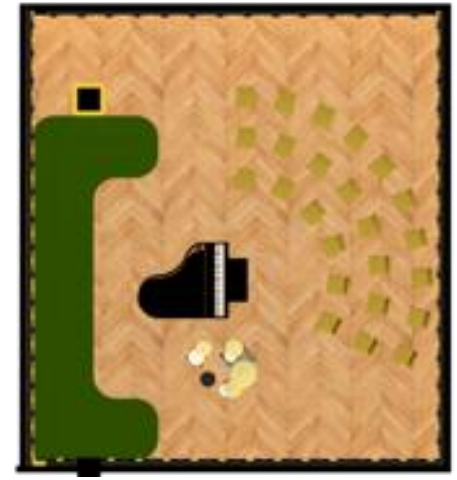

Figure 3 Ensemble Room Layout

From the room's layout arrangement, the sound is directed to the center of the room, seen from the choral riser and also the player's chairs that are facing the center of the room where there are drums and piano. The chairs for the music players are made circular so that the players can hear each other's sounds, from other players' musical instruments in order to create a harmonious musical play.

For furniture's upholstery materials, sound-absorbing fabric is used, aiming to balance the functions of floors, walls and ceilings that have used a lot of sound-reflecting wood materials.

\subsection{Walls}

Reffering to an article on the website bettersoundproofing.com [10], wood has a function of reflecting sound better than absorbing sound. However, because it is porous, wood also absorbs a little sound. Perforated woods with an air chamber behind it will effectively dampen sounds over mid to high ranges and absorb bass sounds.

Wood isn't dense enough to absorb a lot of sound. However, wood with holes, grooves, or slits cut can become perforated resonators that reduce sound. Enhancing the porous nature of wood improves its sound absorption ability.

Wooden acoustic panels work by breaking sound waves. Air enters through the holes but the path of the sound waves through the wood is disturbed and can create better sound resonance. Higher frequency waves are reflected and lower frequencies are absorbed.

Diffusion is what happens when sound waves are reflected off a curved or irregular surface such as acoustic wood panels. The sound waves are scattered, eliminating echo or flutter in the room.

Wooden planks or plywood usually have a smooth solid surface that reflects sound. Wooden acoustic panels or panels with curved surfaces will reduce the sound reflected off the walls or ceiling. Sound reflected from a curved surface, or parabola, will reflect sound at an angle to the initial wave based on a curve. It's their reflection ability and curved surfaces that make wooden musical instruments sound so good. 


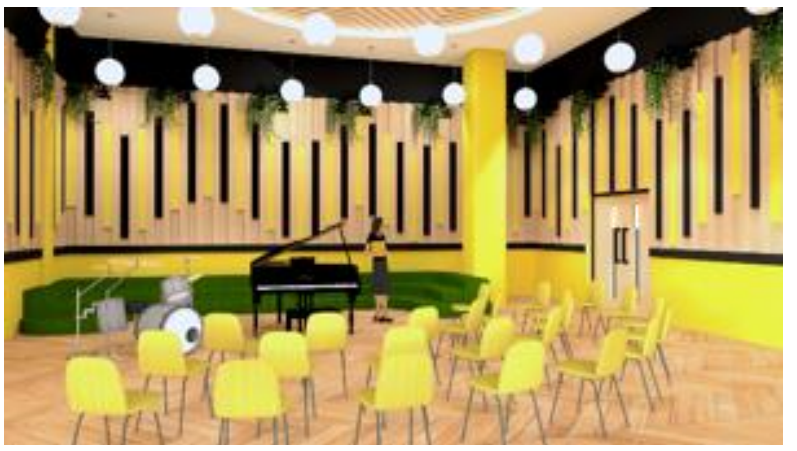

Figure 4 Perspective of Ensemble Room

On the walls of the ensemble room, acoustic panels are used which are arranged unparalleled and unevenly. The wood panels function as diffuser, which is a sound reflector because wood is a hard material that can reflect sound. Meanwhile, the yellow and black panels are fabric coated acoustic panels, which are acoustic panels covered with fabric that function as reverberation control. The panel has an NRC value of 0.85 and the inside of the panel is a sound absorbing glasswool with multiplex framing so that there is little sound reflection function. This material is more effective at absorbing high frequency sounds.

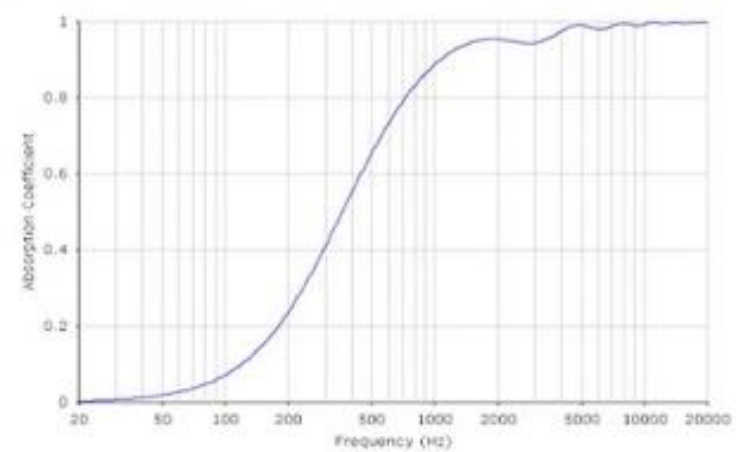

Figure 5 Absorption Coefficient porous absorbent

The majority of the materials on the walls are hard-textured, namely the use of wood acoustic panels so that the majority of the walls function as a diffuser, which is a sound reflector. In addition, a wooden profile with a curved shape is used to concentrate sound to the center of the room and prevent the gathering of sound in the corner of the room.

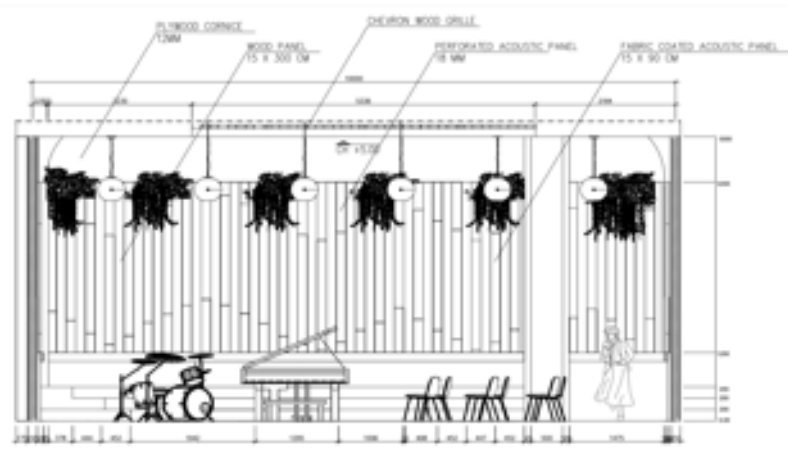

Figure 6 Ensemble Room Elevation
For the partition, a two-face partition filled with $50 \mathrm{~mm}, 33$ $\mathrm{kg} / \mathrm{m} 3$ glasswool with an average NRC of 1.00 is used. Before the partition walls, there is also a space behind the acoustic panel treatment filled with glasswool. The use of 2 layers of glasswool aims to prevent sound leakage due to the position of the room which is adjoining with the auditorium and another ensemble room.

For wood panels on the walls, perforated acoustic panels are used with a small hole with diameter of $3 \mathrm{~mm}$ and $2 \mathrm{~cm}$ distance between the holes.

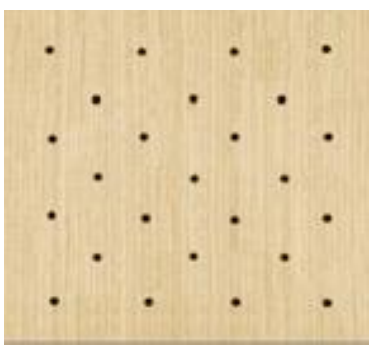

Figure 7 Perforated Acoustic Panel

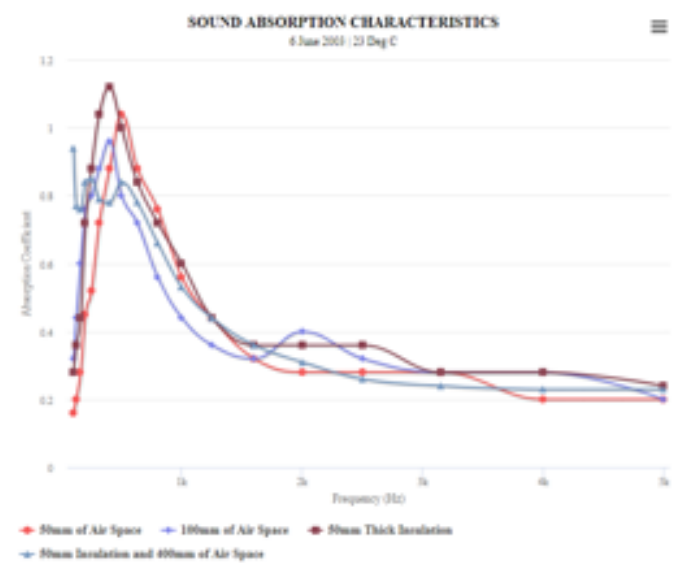

Figure 8 Absorption Characteristic of Perforated Acoustic Panel

The graph shows a higher absorption coefficient level at lower frequencies, indicating that this material is effective at absorbing low frequency sounds. In addition, the material has an acoustic function as an absorber as well as a sound reflector due to the distant gaping holes in the panels and the texture of the panels that is made of wood and hard textured.

Another acoustic function is found in doors that use sound insulation door seals to prevent sound leaks from the door. 


\subsection{Plafond}

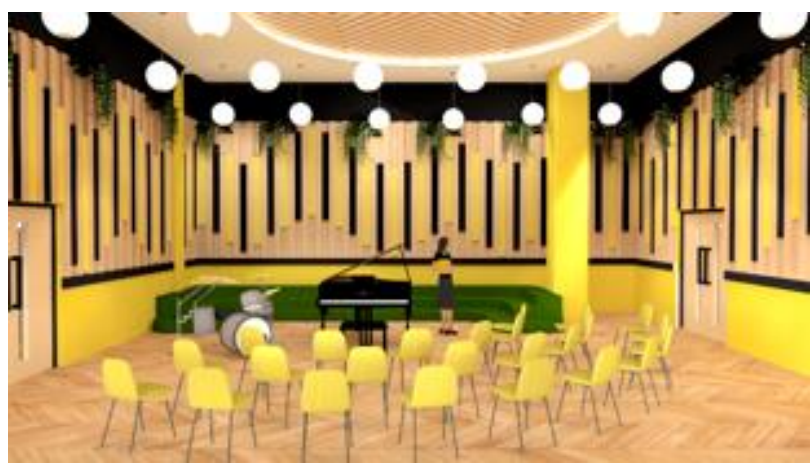

Figure 9 Second Perspective of Ensemble Room

On the ceiling, a wood grille is used with an NRC value of 0.75 . Because it is hollow and is accompanied by the use of glasswool, wood grille functions as a sound absorber. Wood grille is also located in the middle of the room because based on the arrangement of the ensemble room's layout, the sounds are centered in the center of the room, so the sound absorption function in the middle of the room prevents sound accumulation in the center of the room. In addition, because it is a wood based material, wood grille also has a sound reflection function which is balanced by the use of fabric in furniture and Luxury Vinyl Planks with sound - insulating underlayment on the floor.

In an article on the website bettersoundproofing.com [10], it is said that acoustic wood grilles which are also known as a grid or slatted panels and are used on walls and ceilings to reduce sound transfer and echo. The spacing between the wood pieces making up the grill influences their effectiveness at reducing different frequencies of sound. The NRC varies from 0.20 to 0.70 with the grill depth, material, and installation; they are better for larger rooms. On the other hand, there are acoustic ceiling boards as acoustic control for the room as well as a barrier to heat from outside.

\subsection{Floor}

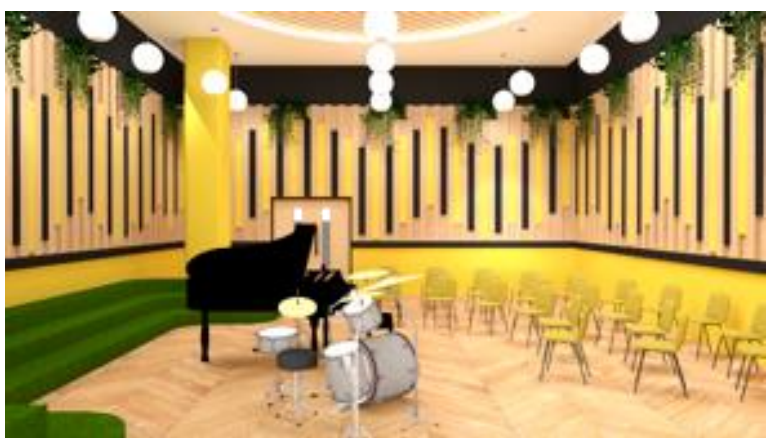

Figure 10 Third Perspective of Ensemble Room

The floor uses Luxury Vinyl Planks which is based with sound-insulating underlayment with an IIC (Impact Insulation Class) value of 58, which functions as a sound suppressor. However, because the luxury vinyl plank has a hard texture, the sounds are not completely absorbed, instead, some are reflected.

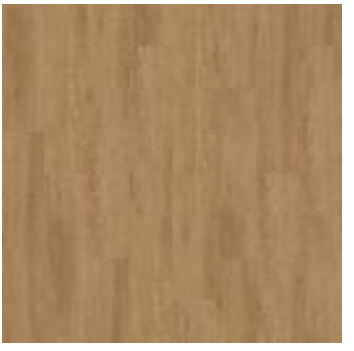

Figure 11 Luxury Vinyl Planks

\begin{tabular}{|c|c|c|c|c|c|c|c|}
\hline & $125 \mathrm{~Hz}$ & $250 \mathrm{~Hz}$ & $500 \mathrm{~Hz}_{2}$ & $1 \mathrm{KHz}$ & $20 \mathrm{OHz}$ & $45 \mathrm{OHz}$ & 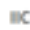 \\
\hline $\begin{array}{l}\text { Quiet } \\
\text { Floor }\end{array}$ & 58 & 56 & 44 & 30 & 20 & 18 & ss \\
\hline
\end{tabular}

Figure 12 IIC Floor Underlayment

\section{CONCLUSIONS}

Purwacaraka College of Music has utilized several applications of materials and acoustic treatments to the composition of the ensemble room to achieve good acoustic quality. From the majority of walls that use hard textured materials with unparalleled and uneven surfaces and structures to provide a diffuse or spreading function of sounds, there are also absorption functions such as the use of double sided partitions filled with glasswool, the use of perforated acoustic wood on the back panel, with room filled with glasswool behind it, giving the sound absorption function on the wall.

For the ceiling and floor, they function as sound absorber with a slight sound reflection function by using the wood grille, as well as the acoustic ceiling board on the ceiling, and the use of sound-insulating underlayment under the luxury vinyl plank on the floor.

In this design, room compositions have used various kinds of acoustic treatments with various considerations related to room acoustics in order to produce good sound quality and in accordance with the function of space such as the use of absorption functions for low frequency sounds (perforated acoustic wood, acoustic ceiling board, etc.) and for high frequency sounds (fabric coated acoustic panels, glasswool, etc.) as well as diffusion functions (acoustic panel wood) because the ensemble room is a space used for various musical instruments so that it requires treatment that can meet the acoustic needs of all musical instruments used in the room as much as possible.

Of course, this design is still far from perfect and it still has many deficiencies in the application of acoustic science to design because of the limited understanding and deepening of acoustic knowledge.

In the future, it is hoped that writers can explore and understand more about acoustic science and its implementation to spatial compositions. 


\section{REFERENCES}

[1] Alfajar, S., Riskiyanto, R., \& Indrosaptono, D. (2014). Perencanaan Dan Perancangan Sekolah Tinggi Musik Semarang. Architectural Journal. Vol.3(3). 1. https://ejournal3.undip.ac.id/index.php/imaji/article/vie w/5627/5415

[2] Blythe, S.G. (2017). Attention, Balance and Coordination: The A.B.C. of Learning Success. New Jersey: John Wiley \& Sons.

[3] Doelle, L.L. (2010). Akustik Lingkungan. Jakarta: Erlangga.

[4] Kamus Besar Bahasa Indonesia. (n.d) Akustika. In Kamus Besar Bahasa Indonesia (KBBI). Retrieved January 18, from https://kbbi.web.id/akustika.

[5] Kencanawati, C.I.P. Kusuma. (2017). Akustik, Noise Dan Material Penyerap Suara. Lecture Notes. Udayana University. Retrieved from https://simdos.unud.ac.id/ uploads/file_pendidikan_1_dir/8fd00a708e84a556c9db a885cc89bec 2 .pdf

[6] Mediastika, C.E. (2005). Akustika Bangunan. Jakarta: Erlangga

[7] Moleong, L. J. (2007). Metodologi Penelitian Kualitatif. Bandung: Remaja Rosdakarya.

[8] Riduan, O. (2010). Designing small music practice rooms for sound quality. Proceedings of 20th International Congress on Acoustics, August 2010. Vol.1-2. https://www.acoustics.asn.au/conference_ proceedings/ICA2010/cdrom-ICA2010/papers/p754.pdf

[9] Yudana, B. (1996). Kerajinan Tangan dan Kesenian Seni Musik. Surakarta: Cahaya Ilmu.

[10] bettersoundproofing.com. (2019, April 13). Does Wood Absorb or Reflect Sound? Retrieved January 18, from https://bettersoundproofing.com/does-woodabsorb-or-reflect-sound/ 